\title{
Initial Growth and Nutrition of Eucalyptus Under Different Management of Harvest Residues
}

\author{
Jackson Freitas Brilhante de São José ${ }^{1}$ (1) 0000-0002-4637-0299 \\ Luciano Kayser Vargas ${ }^{1}$ (D) 0000-0002-1721-1061 \\ Cimélio Bayer ${ }^{2}$ @ 0000-0001-8553-7330 \\ Bruno Brito Lisboa ${ }^{1}$ (D) 0000-0003-3258-2300 \\ Elias Frank de Araújo $^{3}$ (1) 0000-0002-7635-5305
}

\begin{abstract}
The management of eucalyptus harvest residues can affect the initial growth and nutrient content of new eucalyptus plantations. We investigated the initial growth and nutritional status of Eucalyptus saligna plantation according to five alternative strategies for management of harvest residues on sandy soil, in the municipality of Barra do Ribeiro, RS. The total height, diameter at breast height $(\mathrm{DBH})$, individual volume and nutrient content in the leaves were evaluated after twelve months. We observed that the maintenance of harvest residues increased growth in height, $\mathrm{DBH}$ and individual volume. The levels of calcium in leaves of eucalyptus were higher in the treatments in which harvest residues were removed, whereas the opposite was confirmed for sulfur. The differences found in our study point that the maintenance of harvest residues increase the eucalyptus growth, especially in sandy soils.
\end{abstract}

Keywords: tree growth, nutrient content, bark, quartzipsamment.

\section{INTRODUCTION AND OBJECTIVES}

Forest plantations occupy an area of about 200 million ha in the world, in order to attend the increased demand for wood and also to sequester carbon dioxide from the atmosphere (Zhang et al., 2012). In Brazil, the area with planted forests occupies approximately 7.74 million ha, comprising species of the genera Eucalyptus, Pinus, Acacia and Tectona (Iba, 2017). This area is expected to grow by 3.0 million ha by 2020 due to the goal of the National Plan for Low Carbon Agriculture (MAPA, 2010). The state of Rio Grande do Sul contributes with 780 thousand ha, being Eucalyptus the predominant species (Ageflor, 2017).

In Brazil, these eucalyptus plantations have been established in areas with predominantly low-fertility soils that are highly dependent upon nutrient cycling through plant litter and the decomposition of harvest residues (HR). Recently, several reports have attempted to understand the effects of forest harvest residues on the sustainability of eucalyptus forest production (Jesus et al., 2015). The removal or maintenance of the harvest residues is a cause of debate in the international scientific community (Achat, Deleuze et al., 2015; Carneiro et al., 2009; Kumaraswamy et al., 2014). On one side, many studies recommend keeping the harvest residues on soil to avoid the risk of nutrient depletion. The maintenance of forest harvests residues brings advantages by promoting the initial growing of trees (Laclau et al., 2010) due to the improvement of soil characteristics such as the availability of soil nutrients (Hernández et al., 2016; Menegale et al., 2016; Mendham et al., 2014) and soil organic matter (Achat, Fortin et al., 2015; Epron et al., 2015), as well as the soil microbial activity (Nambiar \& Harwood, 2014; Wu et al., 2011).

On the other side, there is an increasing demand for energy from renewable sources, which has stimulated the use of forest residues for energy generation purposes in Brazil and in the world in recent decades. The reasons for using forest residues are not only of environmental concern, but also due to its technical and economic viability (Ribeiro

\footnotetext{
${ }^{1}$ Secretaria da Agricultura, Pecuária e Desenvolvimento Rural do Rio Grande do Sul (SEAPDR), Porto Alegre, RS, Brasil

${ }^{2}$ Universidade Federal do Rio Grande do Sul (UFRGS), Porto Alegre, RS, Brasil

${ }^{3}$ CMPC Celulose Riograndense, Guaíba, RS, Brasil
} 
et al., 2017). In this context, Gustavsson et al. (2015) point out the large climate benefits when forest residues are collected for energy services, in substitution to coal, providing great climate change mitigation benefits. Additionally, other authors point out the economic and energetic advantages of using forest residues for the production of biogas (Kabir et al., 2014) or charcoal (Brown et al., 2013). Despite the importance of the subject, there are only a few studies dedicated to understand the importance of maintenance of forest harvest residues in Brazil, especially in sandy soils with low cation exchange capacity, fertility and storage water. Thus, our study sought to understand the impact of different managements that harvest residue retention has on initial growth and nutritional assessment in eucalypt. We tested the hypothesis that residue maintenance would increase initial growth and leave concentration of nutrients in sandy soil in southern Brazil.

\section{MATERIALS AND METHODS}

\subsection{Study site}

The experimental trial was conducted in the municipality of Barra do Ribeiro, RS. The area of study is located at the geographic coordinates of latitude $30^{\circ} 23^{\prime} 36.68^{\prime \prime} \mathrm{S}$ and longitude $51^{\circ} 7^{\prime} 57.70^{\prime \prime} \mathrm{W}$. According to the Köppen classification, the prevailing climate in the region is of the Cfa type (humid subtropical) with an average annual rainfall of about $1400 \mathrm{~mm}$. The average temperature of the warmest month does not exceed $25^{\circ} \mathrm{C}$ and $14{ }^{\circ} \mathrm{C}$ in the coldest month, with light frosts. A 7-year-old Eucalyptus saligna plantation for pulp production was harvested at the study site in May 2010. The plantation had a 1666 trees ha ${ }^{-1}$ stand density, with $38.3 \mathrm{~m}^{3}$ ha $^{-1}$ year ${ }^{-1}$, and a $480 \mathrm{~kg} \mathrm{~m}^{-3}$ basic wood density, which is within the average for E. saligna species in the area. The soil at the site was classified as Quartzipsamment (Santos et al., 2013).

\subsection{Aerial biomass and nutrient stock of the first rotation}

An inventory of tree diameter at breast height $(\mathrm{DBH})$ and tree height was used to select fifteen average sized trees. The trees were felled using a mechanical harvester. Each tree was fractioned into branches, bark and leaves. Samples of each part were weighed separately, after being dried at $65^{\circ} \mathrm{C}$ until a constant weight, and a sample was taken to determine the moisture and nutrient content (Table 1).

Table 1. Aerial biomass production (dry matter), nutrient concentration, and amounts of nutrients accumulated in each fraction of a harvest of a seven-year-old Eucalyptus saligna plantation; means and mean standard deviations (between parentheses).

\begin{tabular}{|c|c|c|c|c|c|c|c|c|c|c|c|c|c|}
\hline \multirow[t]{2}{*}{ Aerial part } & \multirow{2}{*}{$\begin{array}{l}\text { Biomass } \\
\text { Mg ha }^{-1}\end{array}$} & $\mathbf{N}$ & $\mathbf{P}$ & $\mathbf{K}$ & $\mathrm{Ca}$ & $\mathrm{Mg}$ & $S$ & $\mathbf{N}$ & $\mathbf{P}$ & $\mathbf{K}$ & $\mathrm{Ca}$ & $\mathrm{Mg}$ & $S$ \\
\hline & & \multicolumn{6}{|c|}{$\mathrm{g} \mathrm{kg}^{-1}$} & \multicolumn{6}{|c|}{$\mathrm{kg} \mathrm{ha}^{-1}$} \\
\hline \multirow[t]{2}{*}{ Leaves } & 0.4 & 19.8 & 1.2 & 1.9 & 12.7 & 3.3 & 1.3 & 6.9 & 5.8 & 0.7 & 4.3 & 1.1 & 0.5 \\
\hline & $(0.3)$ & $(1.6)$ & $(0.3)$ & $(0.4)$ & $(2.8)$ & $(0.4)$ & $(0.1)$ & $(4.9)$ & $(4.4)$ & $(0.5)$ & $(3.0)$ & $(0.8)$ & $(0.3)$ \\
\hline \multirow[t]{2}{*}{ Branches } & 13.0 & 2.6 & 0.2 & 0.5 & 5.4 & 2.7 & 0.4 & 34.7 & 2.3 & 6.2 & 71.6 & 12.0 & 3.0 \\
\hline & (4.3) & $(0.6)$ & $(0.1)$ & $(0.1)$ & (1.5) & $(0.4)$ & $(0.0)$ & (16.4) & $(1.2)$ & (3.3) & $(34.7)$ & $(4.9)$ & $(1.4)$ \\
\hline \multirow[t]{2}{*}{ Bark } & 6.6 & 6.1 & 0.4 & 0.7 & 39.1 & 2.7 & 0.4 & 39.5 & 2.8 & 4.3 & 283.1 & 17.3 & 2.6 \\
\hline & (3.2) & $(0.4)$ & $(0.1)$ & $(0.1)$ & $(2.8)$ & $(0.4)$ & $(0.0)$ & $(20.0)$ & (1.4) & $(2.2)$ & (108.5) & $(8.9)$ & $(1.3)$ \\
\hline \multirow[t]{2}{*}{ Total } & 20.0 & & & & & & & 81.1 & 10.9 & 11.2 & 359.0 & 30.5 & 6.0 \\
\hline & $(4.2)$ & & & & & & & (15.5) & (4.7) & $(5.4)$ & (124.4) & (15.7) & $(2.7)$ \\
\hline
\end{tabular}

\subsection{Experimental design}

After clear-cutting, the seven-year-old Eucalyptus saligna plantation residue layer was homogeneously spread at the site. The experimental design was a randomized complete block design (1.8 ha of total area, Figure 1a) with four replications, established in June 2010 with Eucalyptus saligna.
Each block contained five plots of $10 \times 10$ trees ( 100 trees) at a 1,333 trees ha ${ }^{-1}$ density, with different management levels of forest residue removal. Each plot $\left(900 \mathrm{~m}^{2}\right)$ consisted of an inner plot of 36 trees $(6 \times 6)$, flanked by two buffer rows on all sides (Figure 1b). The treatments were implemented with different management levels of forest residue removal. The treatments tested were: 
1. FRM: all forest residues (bark, branches, leaves and litter layer from the previous rotation) were maintained on the soil, only stem wood were harvested;

2. FRMB: all forest residues (branches, leaves and litter layer from the previous rotation) were maintained on the soil, but only stem wood and bark were harvested;

3. FRMBr: all forest residues (bark, leaves and litter layer from the previous rotation) were maintained

(a)

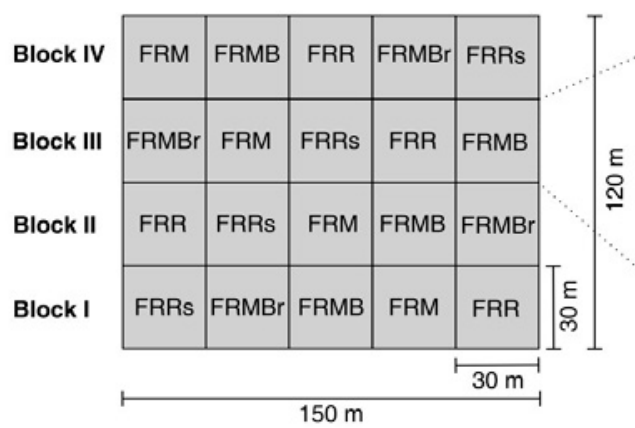

on the soil, but only stem wood and branches were harvested;

4. FRR: all forest residues (bark, branches, leaves and litter layer from the previous rotation) were removed;

5. FRRs: all forest residues (bark, branches, leaves and litter layer from the previous rotation) were removed and litter from new planting was removed by means of a shade net that prevents leaves and branches from falling on the soil surface.

(b)

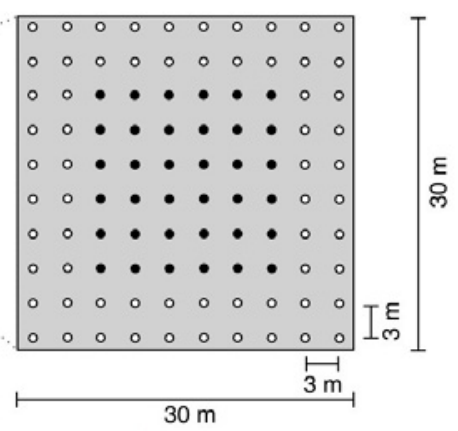

-Eucalyptus - double border

-Eucalyptus - evaluated trees

Figure 1. Schematic representation of trial (a) and the planting designs showing the inner plot comprising 36 trees $(6 \times 6)$ of plot $(b)$.

\subsection{Field procedures}

The treatments were applied and the soil was prepared by subsoiling to $0.4 \mathrm{~m}$ deep with a ripper. The plots were planted with clone 2864 Eucalyptus saligna seedlings in June 2010 (one month after harvesting the first plantation). The base fertilization was 150 g plant $^{-1}$ of NPK 06-30-06. After planting, three topdressing fertilizations were applied in every treatment. In the first two fertilizations, the formula NPK $12-00-20$ with $0.7 \%$ boron was applied around the seedling, within the ground area covered by the canopy, at the thirty and ninety days after planting. In the twelfth month, maintenance fertilization was performed with 225 g plant $^{-1}$ of the formula NPK 24-00-20. Mineral fertilization was conducted based on soil chemical analysis.

\subsection{Soil sampling and analysis}

The soil was collected in June (winter, South Hemisphere), before the tree harvest at first rotation. The soil physical and chemical attributes are shown in Table 2.

Table 2. Soil chemical and physical attributes in the experimental area.

\begin{tabular}{|c|c|c|c|c|c|c|c|c|c|c|}
\hline Depth & O.M & $\underset{\left(\mathbf{H}_{2} \mathrm{O}\right)}{\mathbf{p H}}$ & Al & $\mathbf{H}+\mathbf{A l}$ & $\begin{array}{l}\text { CEC } \\
\text { efet. }\end{array}$ & $\begin{array}{l}\text { CEC } \\
\text { pH } 7\end{array}$ & Ca & Mg & $\mathbf{P}$ & $\mathbf{K}$ \\
\hline$(\mathrm{cm})$ & dag kg $\mathrm{kg}^{-1}$ & & \multicolumn{6}{|c|}{$\mathrm{cmol}_{\mathrm{c}} \mathrm{dm}^{-3}$} & \multicolumn{2}{|c|}{$\mathrm{mg} \mathrm{dm}^{-3}$} \\
\hline $0-20$ & 0.6 & 4.9 & 0.7 & 2.1 & 1.5 & 2.9 & 0.6 & 0.2 & 8.4 & 16.0 \\
\hline $20-40$ & 0.5 & 5.1 & 0.4 & 2.4 & 1.4 & 3.4 & 0.8 & 0.2 & 13.2 & 14.2 \\
\hline $40-60$ & 0.4 & 5.1 & 0.8 & 2.0 & 1.6 & 2.8 & 0.6 & 0.1 & 10.2 & 13.0 \\
\hline $60-80$ & 0.3 & 5.0 & 0.8 & 2.3 & 1.5 & 3.0 & 0.6 & 0.1 & 9.5 & 12.0 \\
\hline $80-100$ & 0.3 & 5.1 & 0.8 & 2.6 & 1.4 & 3.2 & 0.5 & 0.1 & 9.3 & 14.6 \\
\hline Depth & $\mathbf{M}$ & BS & \multicolumn{2}{|c|}{ Sandy coarse } & \multicolumn{2}{|c|}{ Sandy fine } & \multicolumn{2}{|c|}{ Silt } & \multicolumn{2}{|c|}{ Clay } \\
\hline$(\mathrm{cm})$ & \multicolumn{10}{|c|}{$\%$} \\
\hline $0-20$ & 47.1 & 27.7 & \multicolumn{2}{|r|}{93.1} & \multicolumn{3}{|c|}{3.6} & 0.0 & \multicolumn{2}{|c|}{3.3} \\
\hline $20-40$ & 36.0 & 27.0 & \multicolumn{2}{|r|}{92.8} & \multicolumn{2}{|r|}{5.8} & & 0.0 & \multicolumn{2}{|c|}{1.4} \\
\hline $40-60$ & 52.2 & 26.3 & \multicolumn{2}{|r|}{91.9} & \multicolumn{2}{|r|}{6.3} & & 0.0 & \multicolumn{2}{|c|}{1.7} \\
\hline $60-80$ & 56.5 & 22.8 & \multicolumn{2}{|r|}{92.8} & \multicolumn{2}{|r|}{5.0} & & 0.0 & \multicolumn{2}{|c|}{2.2} \\
\hline $80-100$ & 57.6 & 19.3 & \multicolumn{2}{|r|}{92.2} & \multicolumn{2}{|r|}{5.5} & & 0.0 & \multicolumn{2}{|c|}{2.3} \\
\hline
\end{tabular}

P and K: Mehlich ${ }^{-1}$ Extractor; Al, Ca and Mg: KCl 1 mol $^{-1}$ Extractor; $\mathrm{H}+\mathrm{Al}: \mathrm{Ca}(\mathrm{OAc}) 20.5 \mathrm{~mol} \mathrm{l}^{-1} \mathrm{pH} 7.0$

Extractor; O.M.: organic matter; CEC: cation exchange capacity; m: aluminum saturation percentage;

BS: base saturation percentage. 
Soil fertility and soil physical attributes were characterized in three bulked samples, each one composed by four samples, collected at depths $0-20,20-40,40-60,60-80$ and $80-100 \mathrm{~cm}$ before establishment of the trial. At each depth, we measured soil $\mathrm{pH}\left(\mathrm{H}_{2} \mathrm{O}\right)$, organic matter, phosphorus, potassium, calcium, magnesium and exchangeable aluminum, $\mathrm{H}+\mathrm{Al}, \mathrm{CEC}_{\text {effect' }}$, $\mathrm{CEC}_{\mathrm{pH} 7}, \mathrm{~m}$ and $\mathrm{BS}$ according to the methodology described by Tedesco et al. (1995) and granulometric analysis (sandy coarse, sandy fine, silt and clay) was performed by the pipette method (Embrapa, 1997). All analyses were performed in the Laboratory of Soil Analysis of the Universidade Federal do Rio Grande do Sul, Brazil.

\subsection{Tree growth}

The individuals were evaluated after twelve months, with measurements of total height $(\mathrm{H}, \mathrm{m})$, and diameter at breast height $(\mathrm{DBH}, \mathrm{cm})$. The individual volume was estimated by the Equation 1:

$$
\mathrm{VOL}=\frac{\pi \mathrm{DBH}^{2}}{4000}, \mathrm{H} . \mathrm{ff}
$$

VOL: individual volume with bark $\left(\mathrm{m}^{3}\right.$ plot $\left.^{-1}\right)$; ff: form factor of $\mathrm{k} 0.45$.

\subsection{Leaf Nutrient Content}

Leaves were collected in the upper third of the canopy, twelve months after the treatments. We collected twenty fully expanded young leaves from each of the ten trees sampled per plot, forming a bulked sample per plot and totaling four bulked samples to each treatment. Samples were air dried at $65^{\circ} \mathrm{C}$ to a constant weight and ground for chemical determinations of nutrient concentrations. The total $\mathrm{N}$ was determined after sulfuric acid digestion using the micro Kjeldahl method. After nitropercloric digestion, the $\mathrm{P}$ and $\mathrm{B}$ content were determined by colorimetry, $\mathrm{Ca}, \mathrm{Mg}, \mathrm{Fe}, \mathrm{Cu}, \mathrm{Mn}$ and $\mathrm{Zn}$ by atomic absorption spectrophotometry. $\mathrm{K}$ content was determined by flame photometry and $\mathrm{S}$ by turbidimetry (Tedesco et al. 1995).

\subsection{Statistical analysis}

The normality and homogeneity of the variances were checked using the Shapiro-Wilk test $(p>0.05)$ before Anova. After these assumptions were met, the averages were compared by the Tukey's test $(p<0.05)$. The statistical analyses were performed using the PROC GLM procedure as a randomized blocks design (SAS Institute Inc., Cary, NC, USA), according to Equation 2:

$$
Y_{i j}=\mu+\tau_{i}+\beta_{j}+\varepsilon_{i j}
$$

$Y_{i j}$ : dependent variable; $\mu$ : overall mean; $\tau_{i}$ : residue management treatments; $\beta_{j}$ : replication effect (four blocks in different positions of the landscape); $\varepsilon_{i j}$ : experimental error.

\section{RESULTS AND DISCUSSION}

\subsection{Influence of harvest residue management on tree growth}

The analysis of variance of the height, $\mathrm{DBH}$ and wood individual volume data recorded after the experiment showed that there were significant differences among the harvest management residues $(p<0.05)$. The treatment in which all forest residues were maintained on the soil surface (FRM) showed the highest mean values to height, DBH and wood individual volume, whereas the treatments with maximum residue removal, FRR and FRRs, had the lowest values (Table 3).

Table 3. Growth in height $(\mathrm{H})$, diameter at breast height $(\mathrm{DBH})$, and individual volume $(\mathrm{V})$ of clone Eucalyptus saligna after 12 months in different management of harvest residues.

\begin{tabular}{cccc} 
& H & DBH & V \\
\hline & $(\mathbf{m})$ & $(\mathbf{c m})$ & $\left(\mathbf{m}^{3} \mathbf{p l o t}^{-1}\right)$ \\
\hline FRR $^{(1)}$ & $2.19 \mathrm{~b}$ & $1.54 \mathrm{~b}$ & $0.30 \mathrm{~b}$ \\
\hline FRM & $2.89 \mathrm{a}$ & $2.32 \mathrm{a}$ & $0.88 \mathrm{a}$ \\
FRMB & $2.68 \mathrm{ab}$ & $2.09 \mathrm{ab}$ & $0.65 \mathrm{a}$ \\
FRMBr & $2.56 \mathrm{ab}$ & $1.90 \mathrm{ab}$ & $0.52 \mathrm{ab}$ \\
FRRs & $2.20 \mathrm{~b}$ & $1.47 \mathrm{~b}$ & $0.28 \mathrm{~b}$ \\
Mean & 2.50 & 1.86 & 0.53 \\
CV(\%) & 14.46 & 23.23 & 58.32
\end{tabular}

Mean values with the same letter do not differ between them according to the Tukey's test at $p<0.05$.

(1) FRRs: all forest residues (bark, branches, leaves and litter layer from the previous rotation) were removed and litter from new planting was removed using a shade net that prevents leaves and branches from falling on the soil surface; FRM: all forest residues (bark, branches, leaves and litter layer from the previous rotation) were maintained on the soil, only stem wood were harvested; FRMB: all forest residues (branches, leaves and litter layer from the previous rotation) were maintained on the soil, but only stem wood and bark were harvested; FRMBr: all forest residues (bark, leaves and litter layer from the previous rotation) were maintained on the soil, but only stem wood and branches were harvested; FRR: all forest residues (bark, branches, leaves and litter layer from the previous rotation) were removed.

The removal of harvest residues decreases approximately $31 \%$ the growth in height, $50 \%$ of DBH and $62.5 \%$ wood individual volume when compared with the when residues were maintained. These results indicates the important role of maintenance of harvest residues on the surface of soil to initial growing eucalyptus. Our results are corroborated by Soares et al. (2002) and Gómez-Rey (2008), that showed faster early growth when harvest residues are maintained on eucalyptus plantations, when compared with areas where they 
are removed or incorporated to the soil, in Mediterranean conditions. Besides, these results are consistent with those of other authors who found that the maintenance of residues on the surface of soil increased yield in eucalypt when compared with residue removal (Paes et al., 2013; Rocha et al., 2018).

One possible explanation for these results is the fact that the residues maintained on soil surface influenced soil water availability (Mendham et al., 2011) and the supply of nutrients by mineralization over time for eucalyptus trees (Hernández et al., 2009; Nambiar \& Harwood, 2014; Rocha et al., 2016a). Mazurana et al. (2011) found that removal of harvest residues of Eucalyptus grandis presented the greatest loss of nutrients due to soil erosion when compared with their maintenance due to the absence of vegetal material covering the soil surface. Our results are also corroborating with the previous findings of Merino et al. (2003), in rainy areas of Northwest Spain, in which the maintenance of harvest residues significantly improved the growth and nutritional status of trees.

\subsection{Influence of harvest residue management on tree nutritional status}

The nutritional concentration of the leaves of eucalyptus on the different managements is shown in Table 4. In general, significant differences were observed only for $\mathrm{Ca}$ and $\mathrm{S}$ concentrations in the leaves.

Table 4. Concentration of nitrogen $(\mathrm{N})$, phosphorus $(\mathrm{P})$, potassium $(\mathrm{K})$, calcium $(\mathrm{Ca})$, magnesium $(\mathrm{Mg})$ and sulfur $(\mathrm{S})$ in leaves of clone Eucalyptus saligna after 12 months in different management of harvest residues.

\begin{tabular}{ccccccc} 
& N & P & K & Ca & Mg & S \\
\hline \multicolumn{7}{c}{$\mathbf{g ~ k g}^{-1}$} \\
FRR $^{(1)}$ & $20.3 \mathrm{a}$ & $1.6 \mathrm{a}$ & $9.4 \mathrm{a}$ & $4.1 \mathrm{ab}$ & $2.8 \mathrm{a}$ & $0.9 \mathrm{~b}$ \\
FRM & $19.7 \mathrm{a}$ & $1.5 \mathrm{a}$ & $9.4 \mathrm{a}$ & $3.6 \mathrm{~b}$ & $2.6 \mathrm{a}$ & $1.2 \mathrm{ab}$ \\
FRMB & $21.5 \mathrm{a}$ & $1.7 \mathrm{a}$ & $9.6 \mathrm{a}$ & $4.1 \mathrm{ab}$ & $2.7 \mathrm{a}$ & $1.5 \mathrm{a}$ \\
FRMBr & $21.6 \mathrm{a}$ & $1.7 \mathrm{a}$ & $9.3 \mathrm{a}$ & $4.1 \mathrm{ab}$ & $2.7 \mathrm{a}$ & $1.4 \mathrm{ab}$ \\
FRRs & $20.7 \mathrm{a}$ & $1.6 \mathrm{a}$ & $8.7 \mathrm{a}$ & $4.4 \mathrm{a}$ & $2.6 \mathrm{a}$ & $1.2 \mathrm{ab}$ \\
Mean & 20.7 & 1.6 & 9.3 & 4.0 & 2.7 & 1.2 \\
\hline CV(\%) & 8.3 & 9.0 & 14.5 & 8.2 & 6.7 & 21.2 \\
\hline
\end{tabular}

Mean values with the same letter do not differ between them according to the Tukey's test at $p<0.05$.

(1) FRRs: all forest residues (bark, branches, leaves and litter layer from the previous rotation) were removed and litter from new planting was removed using a shade net that prevents leaves and branches from falling on the soil surface; FRM: all forest residues (bark, branches, leaves and litter layer from the previous rotation) were maintained on the soil, only stem wood were harvested; FRMB: all forest residues (branches, leaves and litter layer from the previous rotation) were maintained on the soil, but only stem wood and bark were harvested; FRMBr: all forest residues (bark, leaves and litter layer from the previous rotation) were maintained on the soil, but only stem wood and branches were harvested; FRR: all forest residues (bark, branches, leaves and litter layer from the previous rotation) were removed.
In contrast to what was observed concerning the tree growth parameters, the highest concentration of $\mathrm{Ca}$ was found in the FRRs and the lowest concentration in FRM. The decrease of content of Ca may occur due to dilution effects of increased plant growth in FRM. These effects may both decrease and increase the concentrations of elements in plant tissues (Jarrell \& Beverly, 1981). In general, Ca is the second most absorbed nutrient by forest species (Barros et al., 1990). Ca is the most accumulated nutrient in components exported from the production area by the eucalyptus species, since approximately $75 \%$ of that element is exported from the site due to the harvesting of stem wood (Santana et al., 2008). Rocha et al., (2016b) observed that $50 \%$ of the Ca contained in Forest residues had been released 300 days after the harvest. About $68 \%$ of $\mathrm{Ca}$ are exported when the bark is removed, decreasing the nutrient stocks available for the next cycle of planting. Therefore, the maintenance of bark on sites such as sandy soil is very important to maintain sustainability of forestry production.

Regarding $\mathrm{S}$ concentration, the highest concentration was found in FRMB and the lowest in FRRs. One possible explanation is that the retention of harvest residues can, in some cases, conserve soil moisture (O'Connell et al., 2004) and root ionic absorption of $S$ occurs mainly through mass flow, which is a process limited by water availability (Cramer \& Hawkins, 2009). Therefore, $S$ is believed to possibly be more dependent on residue management, which affects an ideal condition of soil moisture.

On the other hand, no significant differences were observed in $\mathrm{N}, \mathrm{P}, \mathrm{K}$ and $\mathrm{Mg}$ concentrations. Our results contrast with those obtained by Vitousek \& Sanford (1986) and Bouillet et al. (2004) that found nitrogen as the most likely nutrient to limit primary production in eucalyptus plantations in tropical sandy soils. Those results could be attributed to the low mineralization rates of these nutrients that were insufficient for optimal growth. In the early years of development, plants consume more $\mathrm{N}$ and $\mathrm{P}$ (Graciano et al., 2006). Thus, the results suggest that, probably, $\mathrm{N}$ and $\mathrm{P}$ were taken from fertilizations, since these nutrients are promptly available.

Moreover, one reason for the lack of differences in $\mathrm{K}$ content in leaves is the fact that $\mathrm{K}$ is nonstructural, being rapidly released from plant tissue, that is, it is very labile in decomposing harvest residues, and a large proportion of $\mathrm{K}$ will be released with the first rains that follow harvest. Ferreira et al. (2016) found that about $90 \%$ of $\mathrm{K}$ contained in forest residues had been released in the first year, in eleven sites for eucalypt production in Brazil. This process becomes important mainly in sandy soils or on sites with low cation exchange capacity, where there is a strong possibility of leaching of $\mathrm{K}$ down the soil profile. 
Regarding micronutrients, no significant differences in the concentrations were observed (Table 5).

Table 5. Concentration of zinc $(\mathrm{Zn})$, copper $(\mathrm{Cu})$, manganese $(\mathrm{Mn})$, iron (Fe), in leaves of clone Eucalyptus saligna after 12 months in different management of harvest residues.

\begin{tabular}{ccccc} 
& Zn & Cu & Mn & Fe \\
\hline & \multicolumn{4}{c}{ mg kg $^{-1}$} \\
FRR $^{(1)}$ & $16.1 \mathrm{a}$ & $2,5 \mathrm{a}$ & $336,0 \mathrm{a}$ & $45.8 \mathrm{a}$ \\
FRM & $15.2 \mathrm{a}$ & $2,2 \mathrm{a}$ & $339,3 \mathrm{a}$ & $39.2 \mathrm{a}$ \\
\hline FRMB & $15.2 \mathrm{a}$ & $2,2 \mathrm{a}$ & $360,6 \mathrm{a}$ & $39.4 \mathrm{a}$ \\
\hline FRMBr & $15.9 \mathrm{a}$ & $2,4 \mathrm{a}$ & $354,8 \mathrm{a}$ & $41.9 \mathrm{a}$ \\
\hline FRRs & $14.7 \mathrm{a}$ & $2,1 \mathrm{a}$ & $368.0 \mathrm{a}$ & $40.2 \mathrm{a}$ \\
Mean & 15.4 & 2.3 & 351.7 & 41.3 \\
\hline CV(\%) & 7.2 & 25.4 & 21.0 & 14.0 \\
\hline
\end{tabular}

Mean values with the same letter do not differ between them according to the Tukey's test at $p<0.05$.

(1) FRRs: all forest residues (bark, branches, leaves and litter layer from the previous rotation) were removed and litter from new planting was removed using a shade net that prevents leaves and branches from falling on the soil surface; FRM: all forest residues (bark, branches, leaves and litter layer from the previous rotation) were maintained on the soil, only stem wood were harvested; FRMB: all forest residues (branches, leaves and litter layer from the previous rotation) were maintained on the soil, but only stem wood and bark were harvested; FRMBr: all forest residues (bark, leaves and litter layer from the previous rotation) were maintained on the soil, but only stem wood and branches were harvested; FRR: all forest residues (bark, branches, leaves and litter layer from the previous rotation) were removed.

This result is similar to those found in Caldeira et al. (2015), who did not report significant differences for $\mathrm{Fe}, \mathrm{Mn}$ and $\mathrm{B}$ content in leaves, when evaluating four hybrids of Eucalyptus in early plantations. These results can be attributed to the ability of trees to maintain a balance between the levels of this nutrient in the leaves, despite the higher availability of the element in the presence of harvest residues.

\section{CONCLUSION}

According to our results, we can conclude that the maintenance of harvest residues increased height, DBH and individual volume when compared with the removal of the harvest residues and litterfall. The beneficial effects of maintaining the harvest residues and litterfall for tree growth are probably due to nutrient input to the soil, resulting from the decomposition and mineralization of these materials, as well as the increased water retention in the soil.

Significant differences were not observed in the concentrations of nutrients in leaves, except for S, whose concentration was higher when the harvest residues and litterfall were maintained when compared with the removal of these material.

\section{ACKNOWLEDGEMENTS}

We acknowledge CMPC Celulose Riograndense for the availability of the structure, including technical and support staff, in addition to all the experiment costs. We also would like to thank anonymous reviewers for their valuable comments in early versions of the manuscript.

\section{SUBMISSION STATUS}

Received: 2 Apr. 2018

Accepted: 24 Nov. 2018

Associate editor: Marcos Gervásio Pereira

(D) 0000-0002-1402-3612

\section{CORRESPONDENCE TO}

\section{Jackson Freitas Brilhante de São José}

Departamento de Diagnóstico e Pesquisa Agropecuária, Secretaria da Agricultura, Pecuária e Desenvolvimento Rural do Rio Grande do Sul (SEAPDR), Rua Gonçalves Dias, 570, Menino Deus, CEP 90130-060, Porto Alegre, RS, Brasil

e-mail: jacksonbrilhante1@gmail.com

\section{REFERENCES}

Achat DL, Deleuze C, Landmann G, Pousse N, Ranger J, Augusto L. Quantifying consequences of removing harvesting residues on forest soils and tree growth - a meta-analysis. Forest Ecology Management 2015; 348: 124-141. 10.1016/j.foreco.2015.03.042

Achat DL, Fortin M, Landmann G, Ringeval B, Augusto L. Forest soil carbon is threatened by intensive biomass harvesting. Scientific Reports 2015; 5: 15991. 10.1038/srep15991

Associação Gaúcha de Empresas Florestais - Ageflor. A indústria de base florestal no Rio Grande do Sul, ano base 2017 [Internet]. 2017 [cited 2018 Mar. 10]. Available from: https://bit.ly/32I7bTz

Barros NF, Novais RF, Neves JCL. Fertilidade e correção do solo para o plantio de eucalipto. In: Barros NF, Novais RF, editors. Relação solo-eucalipto. Viçosa: Folha de Viçosa; 1990. p. 127-86.

Bouillet JP, Safou-Matondo R, Laclau JP, Nzila JDD, Ranger J, Deleporte P. Pour une production durable des plantations d'eucalyptus au Congo: la fertilisation. Bois et forêts des tropiques 2004; 279(1): 23-35.

Brown D, Rowe A, Wild P. A techno-economic analysis of using mobile distributed pyrolysis facilities to deliver a forest residue resource. Bioresource Technology 2013; 150: 367-376. 10.1016/j. biortech.2013.10.018

Caldeira DRM, Mielke KC, Silva RP, Martins F, Costa WJ, Angelo AC. Initial assessment and nutritional status of hybrid eucalyptus sp. in the municipality of Colorado do Oeste, Rondônia State - Brazil. African Journal of Agricultural Research 2015; 10(35): 3548-3553. 10.5897/AJAR2015.9862

Carneiro M, Serrão V, Fabião A, Madeira M, Balsemão I, Hilário L. Does harvest residue management influence biomass and nutrient accumulation in understory vegetation of Eucalyptus globulus Labill. 
plantations in a Mediterranean environment? Forest Ecology and Management 2009; 257(2): 527-535. 10.1016/j.foreco.2008.09.027

Cramer MD, Hawkins HJ. A physiological mechanism for the formation of root casts. Palaeogeography, Palaeoclimatology, Palaeoecology 2009; 274(3-4): 125-133. 10.1016/j.palaeo.2008.12.021

Empresa Brasileira de Pesquisa Agropecuária - Embrapa. Manual de métodos de análise de solo. 2nd ed. Rio de Janeiro; 1997. 212 p.

Epron D, Mouanda L, Mareschal L, Koutika L-S. Impacts of organic residue management on the soil $\mathrm{C}$ dynamics in a tropical eucalypt plantation on a nutrient-poor sandy soil after three rotations. Soil Biology and Biochemistry 2015; 85: 183-189. 10.1016/j. soilbio.2015.03.010

Ferreira GWD, Soares EMB, Oliveira FCC, Silva IR, Dungait JAJ, Souza IF, Vergütz L. Nutrient release from decomposing Eucalyptus harvest residues following simulated management practices in multiple sites in Brazil. Forest Ecology and Management 2016; 370: $1-11$.

Gómez-Rey MX, Vasconcelos E, Madeira M. Effects of eucalypt residue management on nutrient leaching and soil properties. European Journal of Forest Research 2008; 127(5):379-386. 10.1007/ s10342-008-0217-7

Graciano C, Goya JF, Frangi JL, Guiament JJ. Fertilization with phosphorus increases soil nitrogen absorption in young plants of Eucalyptus grandis. Forest Ecology and Management 2006; 236(2-3): 202-210. 10.1016/j.foreco.2006.09.005

Gustavsson L, Haus S, Ortiz CA, Sathre R, Truong NL. Climate effects of bioenergy from forest residues in comparison to fossil energy. Applied Energy 2015; 138(1): 36-50. 10.1016/j.apenergy.2014.10.013

Hernández J, del Pino A, Salvo L, Arrarte G. Nutrient export and harvest residue decomposition patterns of a Eucalyptus dunnii Maiden plantation in temperate climate of Uruguay. Forest Ecology Management 2009; 258(2): 92-99. 10.1016/j.foreco.2009.03.050

Hernández J, del Pino A, Hitta M, Lorenzo M. Management of forest harvest residues affects soil nutrient availability during reforestation of Eucalyptus grandis. Nutrient Cycling in Agroecosystems 2016; 105(2): 141-155. 10.1007/s10705-016-9781-2

Indústria Brasileira de Árvores - IBA. Anuário estatístico, ano base 2017 [Internet]. 2017 [cited 2018 Mar. 10]. Avaliable from: https:// bit.ly/2VGZRWB

Jarrell WM, Beverly RB. The dilution effect in plant nutrition studies. Advances in Agronomy 1981; 34: 197-224. 10.1016/S00652113(08)60887-1

Jesus GL, Silva IR, Almeida LFJ, Santos MA, Leite FP, Neves JCL. Produtividade do eucalipto, atributos físicos do solo e frações da matéria orgânica influenciadas pela intensidade de tráfego e resíduos de colheita. Revista Brasileira de Ciência do Solo 2015; 39(4): 1190-1203.

Kabir MM, Rajendran KJ, Taherzadeh M, Horváth I. Experimental and economical evaluation of bioconversion of forest residues to biogas using organosolv pretreatment. Bioresource Technology 2014; 178: 201-208. 10.1016/j.biortech.2014.07.064

Kumaraswamy S, Mendham DS, Grove TS, O’Connell AM, Sankaran KV, Rance SJ. Harvest residue effects on soil organic matter, nutrients and microbial biomass in eucalypt plantations in Kerala, India. Forest Ecology Management 2014; 328: 140-149.
Laclau JP, Ranger J, Gonçalves JLDM, Maquère V, Krusche AV, Thongo M'bou A, Nouvellon Y et al. Biogeochemical cycles of nutrients in tropical Eucalyptus plantations: main features shown by intensive monitoring in Congo and Brazil. Forest Ecology and Management 2010; 259(9): 1771-1785.

Mazurana M, Baptista J, Levien R, Conte O. Balanço de nutrientes em povoamento de Eucalyptus saligna implantado sobre Cambissolo Háplico no RS. Revista Brasileira de Engenharia Agrícola e Ambiental 2011; 15(9): 924-929. 10.1590/S1415-43662011000900008

Mendham DS, Ogden GN, Short T, O'Connell TM, Grove TS, Rance SJ. Repeated harvest residue removal reduces E. globulus productivity in the 3 rd rotation in south-western Australia. Forest Ecology Management 2014; 329: 279-286.

Mendham DS, White DA, Battaglia M, McGrath JF, Short TM, Ogden GN, Kinal J. Soil water depletion and replenishment during first- and early second-rotation Eucalyptus globulus plantations with deep soil profiles. Agricultural and Forest Meteorology 2011; 151(12): 1568-1579.

Menegale MLC, Rocha JHT, Harrison R, Gonçalves JLM, Almeida RF, Piccolo MC, Hübner A et al. Effect of timber harvest intensities and fertilizer application on stocks of soil C, N, P, and S. Forests 2016; 7: 319-333. 10.3390/f7120319

Merino A, López AR, Brañas J, Rodriguez-Soalleiro R. Nutrition and growth in newly established plantations of Eucalyptus globulus in north western Spain. Annals of Forest Science 2003; 60: 6: 509517. 10.1051/forest:2003044

Ministério da Agricultura Pecuária e Abastecimento - MAPA. Programa $A B C$ - agricultura de baixa emissão de carbono. Brasília; 2010.

Nambiar EKS, Harwood CE. Productivity of acacia and eucalypt plantations in Southeast Asia. 1. Bio-physical determinants of production: opportunities and challenges. International Forestry Review 2014; 16(2): 225-248. 10.1505/146554814811724757

O'Connell AM, Grove TS, Mendham DS, Rance SJ. Impact of harvest residue management on soil nitrogen dynamics in Eucalyptus globulus plantations in would western Australia. Soil Biology and Biochemistry 2004; 36(1): 39-48. 10.1016/j.soilbio.2003.08.017

Paes FASV, Lima AMN, Hakamada RE, Barros NF. Impacto do manejo dos resíduos da colheita, do preparo do solo e da adubação na produtividade de eucalipto. Revista Brasileira de Ciências do Solo 2013; 37: 1081-1090.

Ribeiro GBDD, Isbaex C, Valverde SR. Produção de biomassa florestal para energia em sistemas agroflorestais. Pesquisa Florestal Brasileira 2017; 37(92): 605-618. 10.4336/2017.pfb.37.92.1389

Rocha JHT, Gonçalves JLDM, Gava JL, Godinho TDO, Melo EASC, Bazani JH, Hubner A et al. Forest residue maintenance increased the wood productivity of a Eucalyptus plantation over two short rotations. Forest Ecology Management 2016a; 379: 1-10. 10.1016/j. foreco.2016.07.042

Rocha JHT, Marques ERG, Gonçalves JLDM, Hubner A, Brandani $\mathrm{CB}$, Ferraz ADV, Moreira RM. Decomposition rates of forest residues and soil fertility after clear-cutting of Eucalyptus grandis stands in response to site management and fertilizer application. Soil Use and Management 2016b; 33(3): 289-302. 10.1111/sum.12283

Rocha JHT, Gonçalves JLDM, Brandani CB, Ferraz ADV, Franci AF, Marques ERG, Arthur JC Jr et al. Forest residue removal decreases 
soil quality and affects wood productivity even with high rates of fertilizer application. Forest Ecology Management 2018; 430: 188195. 10.1016/j.foreco.2018.08.010

Santana RC, Barros NF, Novais RF, Leite HG, Comerford NB. Alocação de nutrientes em plantios de eucalipto no Brasil. Revista Brasileira de Ciência do Solo 2008; 32(spe): 2723-2733.

Santos HG, Almeida JA, Oliveira JB, Lumbreras JF, Anjos LHC, Coelho MR, Jacomine PKT et al. Sistema brasileiro de classificação de solos. 3rd ed. Brasília: Embrapa; 2013. 353 p.

Soares H, Madeira M, Fabião A, Azevedo A, Kätterer T, Abreu F, Cortez N. Efeitos da gestão de resíduos de abate no crescimento inicial de Eucalyptus globulus Labill.: resultados de um estudo lisimétrico. Revista de Ciências Agrárias 2002; 25(3): 394-410.
Tedesco MJ, Gianello C, Bissani CA, Bohnen H. Volkweiss SJ. Análise de solo, plantas e outros materiais. 2nd ed. Porto Alegre: Universidade Federal do Rio Grande do Sul; 1995. 147 p.

Vitousek PM, Sanford RL. Nutrient cycling in moist tropical forest. Annual Review of Ecolology and Systematics 1986; 17: 137-67. 10.1146/annurev.es.17.110186.001033

Wu J, Liu Z, Wang X, Sun Y, Zhou L, Lin Y, Fu S. Effects of understory removal and tree girdling on soil microbial community composition and litter decomposition in two Eucalyptus plantations in South China. Functional Ecology 2011; 25(4): 921-931. 10.1111/j.13652435.2011.01845.x

Zhang D, Zhang J, Yang BW, Wu F. Effects of afforestation with Eucalyptus grandis on soil physicochemical and microbiological properties. Soil Research 2012; 50(2): 167-176. 10.1071/SR11104 